\title{
LC-MS, GC-MS, and NMR Spectroscopic Analysis of Withania somnifera (Ashwagandha) Root Extract After Treatment with the Energy of Consciousness (The Trivedi Effect $^{\circledR}$ )
}

\author{
Mahendra Kumar Trivedi ${ }^{1}$, Alice Branton ${ }^{1}$, Dahryn Trivedi ${ }^{1}$, Gopal Nayak ${ }^{1}$, Aileen Carol Lee ${ }^{1}$, \\ Aksana Hancharuk ${ }^{1}$, Carola Marina Sand ${ }^{1}$, Debra Jane Schnitzer ${ }^{1}$, Rudina Thanasi ${ }^{1}$, \\ Eileen Mary Meagher', Faith Ann Pyka', Gary Richard Gerber', Johanna Catharina Stromsnas ${ }^{1}$, \\ Judith Marian Shapiro ${ }^{1}$, Laura Nelson Streicher ${ }^{1}$, Lorraine Marie Hachfeld ${ }^{1}$, \\ Matthew Charles Hornung ${ }^{1}$, Patricia M. Rowe ${ }^{1}$, Sally Jean Henderson ${ }^{1}$, Sheila Maureen Benson ${ }^{1}$, \\ Shirley Theresa Holmlund ${ }^{1}$, Stephen P. Salters ${ }^{1}$, Parthasarathi Panda ${ }^{2}$, Snehasis Jana ${ }^{2}$, \\ ${ }^{1}$ Trivedi Global, Inc., Henderson, Nevada, USA \\ ${ }^{2}$ Trivedi Science Research Laboratory Pvt. Ltd., Bhopal, Madhya Pradesh, India
}

Email address:

publication@trivedieffect.com (S. Jana)

${ }^{*}$ Corresponding author

To cite this article:

Mahendra Kumar Trivedi, Alice Branton, Dahryn Trivedi, Gopal Nayak, Aileen Carol Lee, Aksana Hancharuk, Carola Marina Sand, Debra Jane Schnitzer, Rudina Thanasi, Eileen Mary Meagher, Faith Ann Pyka, Gary Richard Gerber, Johanna Catharina Stromsnas, Judith Marian Shapiro, Laura Nelson Streicher, Lorraine Marie Hachfeld, Matthew Charles Hornung, Patricia M. Rowe, Sally Jean Henderson, Sheila Maureen Benson, Shirley Theresa Holmlund, Stephen P. Salters, Parthasarathi Panda, Snehasis Jana. LC-MS, GC-MS, and NMR Spectroscopic Analysis of Withania somnifera (Ashwagandha) Root Extract After Treatment with the Energy of Consciousness (The Trivedi Effect $^{(\mathbb{B}}$ ). European Journal of Biophysics. Vol. 5, No. 2, 2017, pp. 27-37. doi: 10.11648/j.ejb.20170502.11

Received: February 6, 2017; Accepted: February 18, 2017; Published: March 9, 2017

\begin{abstract}
Withania somnifera (Ashwagandha) root extract is very popular ancient herbal medicine. The current study was designed to investigate the impact of The Trivedi Effect ${ }^{\circledR}$ - Energy of Consciousness Healing Treatment on the structural characterization of the ashwagandha root extract using LC-MS, GC-MS, and NMR spectroscopy. Ashwagandha root extract was divided into two parts - one part was control, without any Biofield Energy Healing Treatment, while another part was treated with the Biofield Energy Healing Treatment remotely by eighteen renowned Biofield Energy Healers and defined as the Biofield Energy Treated sample. The retention time of the phytoconstituents remained same in both the control and treated samples, whereas the peak area $\%$ at respective retention time was significantly altered. The peak area $\%$ of the treated sample at $\mathrm{R}_{\mathrm{t}}$ of $5.35,5.55,5.94,6.25,6.63,6.76,7.92,8.04,8.60,8.73$, and $9.31 \mathrm{~min}$ were significantly reduced by $6.15 \%$ to $60.67 \%$ compared with the control sample at $\mathrm{R}_{\mathrm{t}}$ of $5.43,5.65,5.95,6.29,6.76,6.85,8.03,8.14,8.68,8.78$, and 9.30 min. Consequently, the peak area $\%$ of the treated sample at $\mathrm{R}_{\mathrm{t}}$ of $7.25,7.30,8.27$, and 8.47 min were significantly increased by $26.32 \%, 7.99 \%$, $16.93 \%$ and $7.97 \%$ compared with the control sample at $\mathrm{R}_{\mathrm{t}}$ of $7.37,7.41,8.36$, and 8.55 min, respectively. A total of 13 withanolides were proposed with their structure from the deduced molecular mass at $m / z 470,472,488,504,782$, and 991 through LC-MS, GC-MS, ${ }^{1} \mathrm{H}$ and ${ }^{13} \mathrm{C}$ NMR analysis of both the control and treated samples. Viscosa lactone B, 27-hydroxy withanolide $\mathrm{A},(20 S, 22 R)$ - $\alpha, 6 \alpha$-epoxy- $\beta, 5 \beta, 27$-trihydroxy-1-oxowitha-24-enolide, $(20 S, 22 R)-4 \beta, 5 \beta, 6 \alpha, 27$-tetrahydroxy-1oxo-with-2, 24-dienolide were proposed in the control and treated samples at $\mathrm{R}_{\mathrm{t}}$ of 6.85 and 7.30 min, respectively. Dihydrowithanolide D was only identified in the control sample at $\mathrm{R}_{\mathrm{t}}$ of $7.41 \mathrm{~min}$, whereas withanoside IV or withanoside VI was only present in the Biofield Treated sample at $R_{t}$ of 6.76 min. Withanolide A, withaferin A, withanone, withanolide $D$, ixocarpalactone A and withanolide sulfoxide were found in both the control and treated samples. These findings suggest that The Trivedi Effect ${ }^{\circledR}$ - Energy of Consciousness Healing Treatment could be beneficial for altering the concentration of the phytoconstituents in the ashwagandha root extract by modifying their intrinsic physicochemical properties, which might be
\end{abstract}


helpful to improve the bioavailability of active constituents of $W$. somnifera extract that might provide better therapeutic response against inflammatory diseases, immunological disorders, stress, arthritis, cancer, diabetes, sexual disorders, aging and other chronic infections.

Keywords: Biofield Energy Healing Treatment, Biofield Energy Healers, Consciousness Energy Healing Treatment, The Trivedi Effect ${ }^{\circledR}$, LC-MS, Retention Time, Withanolides, Withania somnifera, GC-MS, NMR

\section{Introduction}

Now-a-days herbal medicines have been getting importance throughout the world for the prevention and treatment of the various diseases because of their impressive therapeutic effects and fewer side effects as compared to the modern medicines [1]. The roots of Withania somnifera (L.) Dunal (Family- Solanaceae) is an ancient Rasayana herb and is popularly known as 'Ashwagandha' or winter cherry or 'Indian ginseng' (In Ayurveda) [2, 3]. W. somnifera is mostly used in the herbal drugs and nutraceuticals for the prevention and treatment of various diseases include nervous and sexual disorders, infectious diseases, diabetes, cancer, ulcer, immunological disorders, stress, arthritis, etc. As a tonic, it is useful to arrest the aging process, rejuvenate the body and boost the defense system against infectious disorders as well as to promote the longevity [2-6]. The major active phytoconstituents of $W$. somnifera root extract are highly oxygenated withanolides. Besides withanolides, ashwagandha root contains alkaloids, numerous sitoindosides, withanamides, starch, reducing sugars, peroxidases, glycosides, dilcitol, withanicil, benzyl alcohol, 2-phenyl ethanol, benzoic acid phenyl acetic acid, 3, 4, 5trihydroxy cinnamic acid, etc. [7-9]. Isolated withanolides from $W$. somnifera possess various pharmacological activities include antioxidant, anticancer, immunomodulating, neuroprotective, hepatoprotective, antiinflammatory, antiarthritic, antimicrobial, hypoglycaemic, etc. [10-12]. Therefore, ashwagandha root extract was considered as one of the components in a novel proprietary herbomineral formulation that can be used as nutraceutical supplement for the prevention and treatment of various human disorders.

A unique vital force preserved by every living organisms which is usually believed to create the source of life is corelated with the soul, spirit and mind and is also recognized as prana by the Hindus, $q i$ or $c h i$ by the Chinese, and $k i$ by the Japanese from the ancient-time. Now-a-days, this hypothetical vital force is considered as the Bioenergetics Field. This energy field is infinite, paradimensional and dynamic electromagnetic field surrounding the human body. This is also known as The Biofield Energy. It can easily flow between the human and environment that leads to the continuous movement or matter of energy $[13,14]$. Thus, the human has the capability to harness energy from the earth, the "Universal Energy Field" and transmit it to any living or nonliving object(s) around the globe. The objects always receive the energy and respond in a useful way. This process is known as Biofield Energy Healing
Treatment [15-17]. Biofield (Putative Energy Fields) based Energy Therapies have been practiced worldwide in different health disease profiles [18]. The National Center of Complementary and Integrative Health $(\mathrm{NCCIH})$ has been recognized and accepted Biofield Energy Healing as a Complementary and Alternative Medicine (CAM) health care approach in addition to other therapies, medicines and practices such as natural products, deep breathing, yoga, Tai Chi, Qi Gong, chiropractic/osteopathic manipulation, meditation, massage, special diets, homeopathy, progressive relaxation, guided imagery, acupressure, acupuncture, relaxation techniques, hypnotherapy, healing touch, movement therapy, pilates, rolfing structural integration, mindfulness, Ayurvedic medicine, traditional Chinese herbs and medicines, naturopathy, essential oils, aromatherapy, Reiki, cranial sacral therapy and applied prayer (as is common in all religions, like Christianity, Hinduism, Buddhism and Judaism) [19]. The Biofield Energy Treatment (The Trivedi Effect ${ }^{\mathbb{B}}$ ) has been extensively studied with significant outcomes in many scientific fields such as cancer research [20], altered antimicrobial sensitivity of pathogenic microbes in microbiology [21-23], biotechnology [24, 25], genetics [26, 27], changing the structure of the atom in relation to the various metals, ceramics, polymers and chemicals materials science [2830], altered physical and chemical properties of pharmaceuticals [31, 32], nutraceuticals [33, 34], organic compounds [35-37], and improved overall growth and yield of plants in agricultural science [38, 39].

Modern sophisticated techniques such as highperformance liquid chromatography (HPLC) with photodiode array and evaporative light scattering detection, ultraperformance liquid chromatography (UPLC) electrospray ionization (ESI) normally hyphenated with mass spectrometry, gas chromatography (GC), nuclear magnetic resonance (NMR) are very useful for the metabolite profiling and identification of the crude herbal extract [8, 40-42]. The LC-MS/MS, GC-MS and NMR analysis of W. somnifera hydroalcoholic root extract revealed the presence of several known withanolides including withaferin $\mathrm{A}$, withanolide D, withanoside IV or VI, withanolide sulfoxide, etc. along with two new withanolides $i$. $e$. dihydrowithanolide $\mathrm{D}$ and ixocarpalactone A [43]. For this reason, LC-MS/MS, GCMS, and NMR analysis were conducted in this study for the profiling and structure elucidation of the phytoconstituents of the Biofield Energy Treated (The Trivedi Effect ${ }^{\mathbb{B}}$ ) $W$. somnifera hydroalcoholic root extract. 


\section{Materials and Methods}

\subsection{Chemicals and Reagents}

Withania somnifera (Ashwagandha) root hydroalcoholic extract was procured from Sanat Product Ltd, India. The HPLC grade acetonitrile and Milli Q water were purchased from Merck and Millipore. All other chemicals used in the experiment were of analytical grade available in India.

\subsection{Energy of Consciousness Treatment Strategies}

Ashwagandha root extract powder was one of the components of the new proprietary herbomineral formulation, developed by our research team and it was used per se as the test compound for the current study. The test compound was divided into two parts, one part of the test compound was treated with The Trivedi Effect ${ }^{\circledR}$ - Energy of Consciousness Healing Treatment by renowned Biofield Energy Healers and defined as Biofield Energy Treated sample, while the second part of the test compound did not receive any sort of treatment and defined as untreated or control ashwagandha root extract sample. This Biofield Energy Treatment was provided by the group of eighteen renowned Biofield Energy Healers who participated in this study and performed the Biofield Energy Treatment remotely. Eleven Biofield Energy Healers were remotely located in the U. S. A., four remotely located in Canada, two remotely located in Finland, and one of which was remotely located in Albania, while the test compound was located in the research laboratory of GVK Biosciences Pvt. Ltd., Hyderabad, India. This Biofield Energy Treatment was provided for 5 minutes through Healer's Unique Energy Transmission process remotely to the test compound under the laboratory conditions. None of the Biofield Energy Healers in this study visited the laboratory in person, nor had any contact with the compounds. Similarly, the control compound was subjected to "sham" healers for 5 minutes, under the same laboratory conditions. The sham healer did not have any knowledge about the Biofield Energy Healing Treatment. After that, the Biofield Energy Treated and untreated samples were kept in similar sealed conditions and characterized thoroughly by LC-MS, GC-MS and NMR.

\subsection{Characterization}

\subsubsection{Liquid Chromatography Mass Spectrometry (LC-MS)}

The LC-MS analysis of the test samples were conducted by following the almost same method as mentioned in the recent literature [43] using The Waters ${ }^{\circledR}$ ACQUITY UPLC, Milford, MA, USA equipped with a binary pump (The Waters ${ }^{\circledR}$ BSM HPLC pump), autosampler, column heater and a photo-diode array (PDA) detector. A Triple Quad (Waters Quattro Premier XE, USA) mass spectrometer equipped with an electrospray ionization (ESI) source was used for the mass spectrometric analysis. The control and Biofield Energy Treated extract powders were dissolved in dimethylsulfoxide to afford a $1 \mathrm{mg} / \mathrm{mL}$ stock solution. An aliquot of $2 \mu \mathrm{L}$ of the stock solution was used for LC-MS analysis with a total run time of $25 \mathrm{~min}$. Mass spectra were recorded in the positive ionization mode and with the full scan $(\mathrm{m} / \mathrm{z} 50-1400)$.

Percent change in peak area $(\%), \mathrm{P}$ was calculated using following equation 1 :

$$
\% \text { change in peak area }(\%)=\frac{\left[\mathrm{P}_{\text {Treated }}-\mathrm{P}_{\text {Control }}\right]}{\mathrm{P}_{\text {Control }}} \times 100
$$

Where, $\mathrm{P}_{\text {Control }}$ and $\mathrm{P}_{\text {Treated }}$ are the peak area $(\%)$ of the control and Biofield Energy Treated samples, respectively.

\subsubsection{Gas Chromatography-Mass Spectrometry (GC-MS) Analysis}

GC-MS analysis of the test samples were analyzed by following the same procedure as mentioned in the recent scientific literature [43] with the help of Agilent 7890B with 5977A Mass selective detector, USA equipped with a Quadrupole detector with pre-filter and flame ionization detector (FID). The control and Biofield Energy Treated extract powders were dissolved in dimethylsulfoxide to afford a $1 \mathrm{mg} / \mathrm{mL}$ stock solution. An aliquot of $1.0 \mu \mathrm{L}$ of the stock solution was injected with a total run time of $44.0 \mathrm{~min}$. The identification of analytes was performed using the retention time with a comparison of the mass spectra of the identified substances with references.

\subsubsection{Nuclear Magnetic Resonance (NMR) Analysis}

${ }^{1} \mathrm{H}$ NMR and ${ }^{13} \mathrm{C}$ NMR analysis of the test samples extract powders were performed on a $400 \mathrm{MHZ}$ VARIAN FT-NMR spectrometer and $100.00 \mathrm{MHz}$ on a VARIAN FT-NMR spectrometer, respectively using the same procedure as mentioned in the recent literature [43]. ${ }^{1} \mathrm{H}$ NMR multiplicities were labelled as singlet (s), doublet (d), doublet of doublet (dd), triplet (t), quartet (q), multiplet (m), broad (br), apparent (app). Chemical shifts $(\delta)$ were in parts per million (ppm) relative to the solvent's residual proton chemical shift $\left(\mathrm{CD}_{3} \mathrm{OD}, \delta=3.31,4.80 \mathrm{ppm}\right)$ and solvent's residual carbon chemical shift $\left(\mathrm{CD}_{3} \mathrm{OD}, \delta=49.15 \mathrm{ppm}\right)$.

\section{Results and Discussion}

The liquid chromatograms and their chromatographic data of the samples of $W$. somnifera root hydroalcoholic extract are presented in the Figure 1 and Table 1, respectively. The liquid chromatograms of the control sample showed 15 peaks having the peak area $\%$ greater than 1 . Among of these 15 peaks, only 6 peaks at the $\mathrm{R}_{\mathrm{t}}$ of $6.85,7.41,8.15,8.36,8.55$, and $9.30 \mathrm{~min}$ having higher peak area\% responded to the mass spectrometric analysis and afforded the respective ESI-MS spectrum as shown in the Figure 2 and 3. Consequently, these 15 peaks in the Biofield Energy Treated sample displayed almost same (only $<2 \%$ alteration with the control sample) $R_{t}$ along with significant change in the peak area $\%$. Interestingly, the peak area $\%$ of the Biofield Energy Treated sample at $\mathrm{R}_{\mathrm{t}}$ of 5.35, $5.55,5.94,6.25,6.63,6.76,7.92,8.04,8.60,8.73$, and 9.31 min were significantly decreased in the range of $6.15 \%$ to $60.67 \%$ with respect to the control sample at $\mathrm{R}_{\mathrm{t}}$ of $5.43,5.65$, $5.95,6.29,6.76,6.85,8.03,8.14,8.68,8.78$, and $9.30 \mathrm{~min}$. 


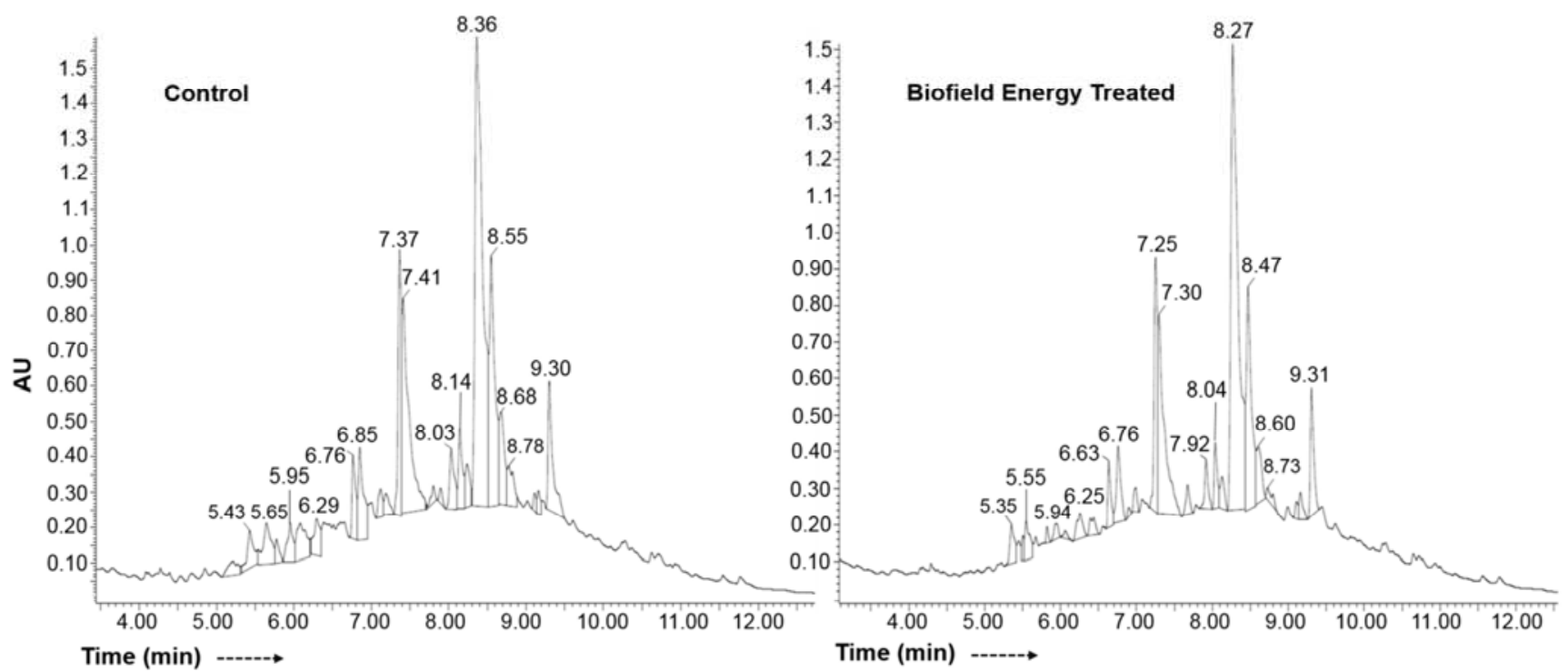

Figure 1. Liquid chromatograms of the control and Biofield Energy Treated W. somnifera (Ashwagandha) root extract.

In addition, the peak area\% of the Biofield Energy Treated sample at $\mathrm{R}_{t}$ of $7.25,7.30,8.27$, and 8.47 min were significantly increased by $26.32 \%, 7.99 \%, 16.93 \%$ and $7.97 \%$ with respect to the control sample at $\mathrm{R}_{t}$ of $7.37,7.41,8.36$, and $8.55 \mathrm{~min}$, respectively. The peak area\% provides the relative amounts of components in the chromatogram, when all components respond equally in the detector and are eluted [43, 44]. Here, the liquid chromatographic conditions for both the control and Biofield Energy Treated samples were same. It is assumed that all the components in both the samples were equally responded in the detector. So, the provided peak area\% are related to the relative amounts of the phytoconstituents of $W$. somnifera root extract.

Table 1. Liquid chromatographic data of both the control and Biofield energy Treated W. somnifera (Ashwagandha) root extract.

\begin{tabular}{|c|c|c|c|c|c|c|}
\hline \multirow{2}{*}{ Sl. No. } & \multicolumn{2}{|l|}{ Control sample } & \multicolumn{2}{|c|}{ Biofield Treated sample } & \multirow{2}{*}{ \% Change in $R_{t}$} & \multirow{2}{*}{$\%$ Changein Peak Area (\%) } \\
\hline & Retention time $\left(\mathbf{R}_{t}\right)$ & Peak Area (\%) & Retention time $\left(\mathbf{R}_{\mathrm{t}}\right)$ & Peak Area (\%) & & \\
\hline 1 & 5.43 & 1.95 & 5.35 & 1.83 & -1.47 & -6.15 \\
\hline 2 & 5.65 & 2.70 & 5.55 & 1.98 & -1.77 & -26.67 \\
\hline 3 & 5.95 & 1.78 & 5.94 & 0.70 & -0.17 & -60.67 \\
\hline 4 & 6.29 & 1.87 & 6.25 & 1.56 & -0.64 & -16.58 \\
\hline 5 & 6.76 & 2.46 & 6.63 & 2.09 & -1.92 & -15.04 \\
\hline 6 & 6.85 & 3.98 & 6.76 & 3.50 & -1.31 & -12.06 \\
\hline 7 & 7.37 & 6.80 & 7.25 & 8.59 & -1.63 & 26.32 \\
\hline 8 & 7.41 & 12.01 & 7.30 & 12.97 & -1.48 & 7.99 \\
\hline 9 & 8.03 & 2.30 & 7.92 & 1.79 & -1.37 & -22.17 \\
\hline 10 & 8.14 & 2.48 & 8.04 & 2.11 & -1.23 & -14.92 \\
\hline 11 & 8.36 & 29.53 & 8.27 & 34.53 & -1.08 & 16.93 \\
\hline 12 & 8.55 & 11.17 & 8.47 & 12.06 & -0.94 & 7.97 \\
\hline 13 & 8.68 & 3.94 & 8.60 & 3.31 & -0.92 & -15.99 \\
\hline 14 & 8.78 & 2.03 & 8.73 & 0.81 & -0.57 & -60.10 \\
\hline 15 & 9.30 & 4.88 & 9.31 & 4.52 & 0.11 & -7.38 \\
\hline
\end{tabular}

*denotes the percentage change in the peak area (\%) of the Biofield Energy Treated sample with respect to the control sample.

The Table 1 revealed that Biofield Energy Healing Treatment might have the significant effect on the relative amount of the phytoconstituents. The reason is assumed that the intrinsic physicochemical properties of ashwagandha root extract such as morphology, particle size, shape, etc. of the compounds that are related to the solubility of the compounds might alter due to the Biofield Energy Healing Treatments [28-35]. 


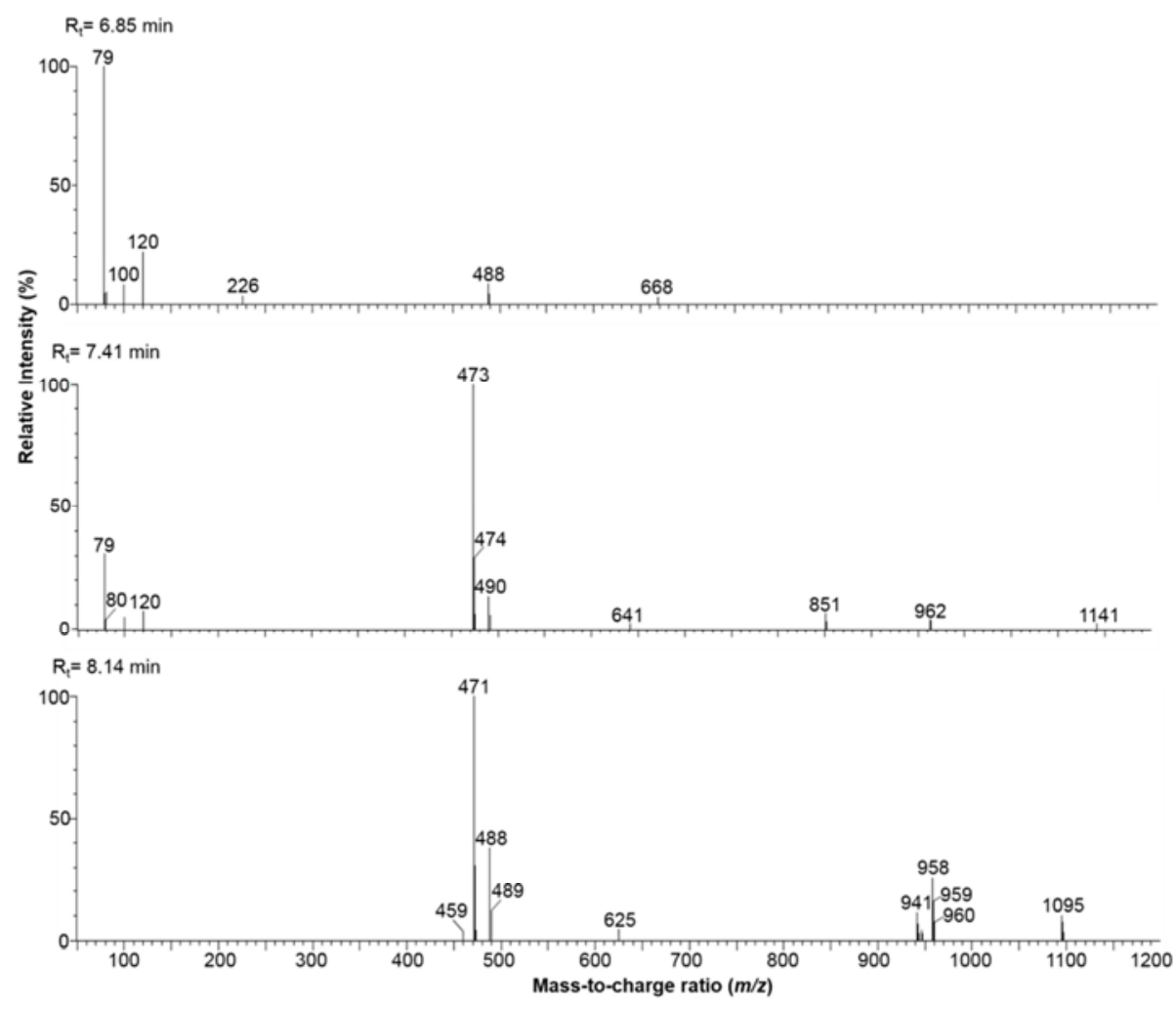

Figure 2. ESI-MS spectrum of the control W. somnifera root (Ashwagandha) extract at the retention time 6.85, 7.41, and 8.15 min.

The ESI-MS spectra of the control sample at the $\mathrm{R}_{\mathrm{t}}$ of $6.85,7.41,8.15,8.36,8.55$, and 9.30 min were only obtained among 15 peaks at different retention times (Figure 1) and are presented in the Figures 2 and 3. Similarly, the ESI-MS spectra of the Biofield Energy Treated sample at the $\mathrm{R}_{\mathrm{t}}$ of $6.76,7.30,8.04,8.27,8.47$, and 9.31 min were only obtained among 15 peaks at different retention times (Figure 1) and are presented in the Figures 4 and 5. Compounds (Figure 6) were proposed from the mass of the molecular ion and its fragmentation pattern at corresponding retention time (Figures 2-5) along with the GC-MS (Figure 7) and NMR data (Figure 8) of the crude extract according to the approach described in our recent literature [43].

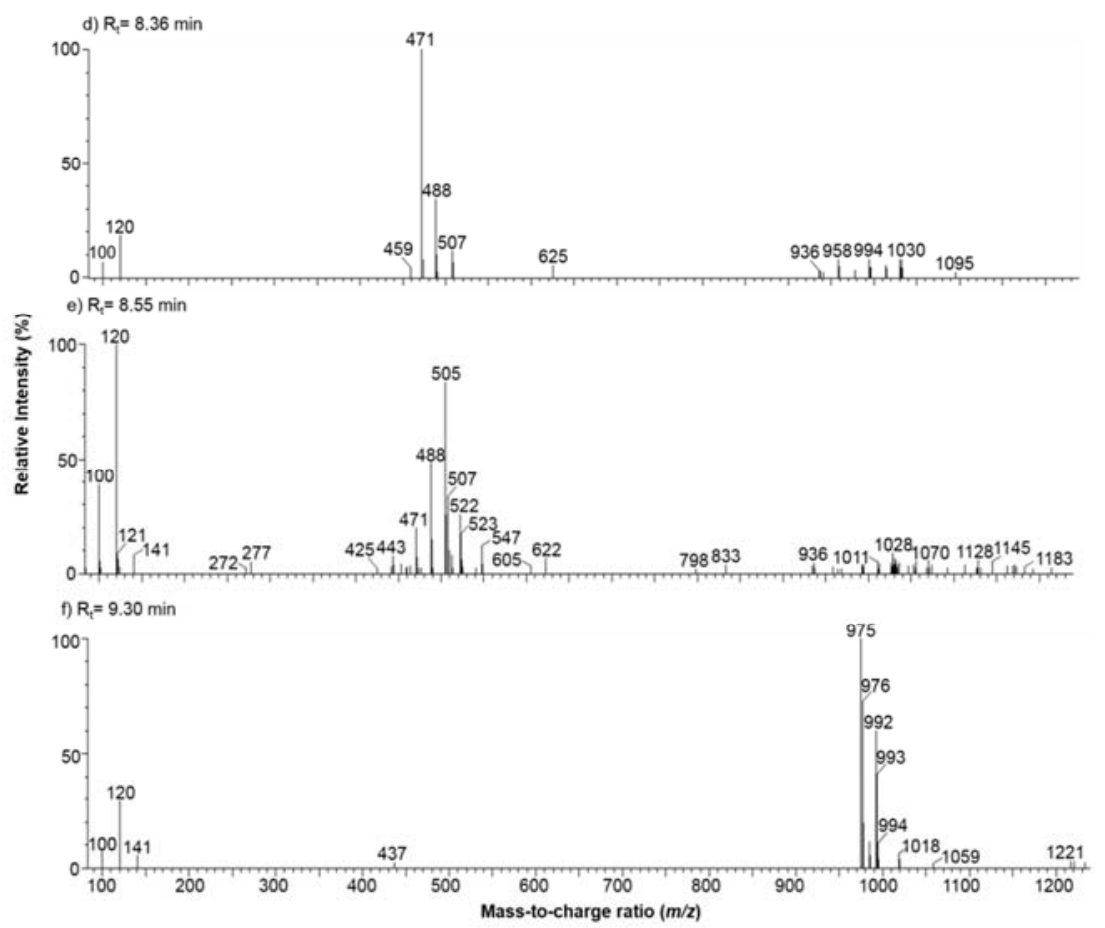

Figure 3. ESI-MS spectrum of the control W. somnifera (Ashwagandha) root extract at the retention time 8.36, 8.55, and 9.30 min. 
Viscosa lactone B (1), 27-hydroxy withanolide A (2), (20S, 22R)-3 $\alpha, 6 \alpha$-epoxy-4 $\beta, 5 \beta, 27$-trihydroxy-1-oxowitha-24-enolide (3), and $(20 S, 22 R)-4 \beta, 5 \beta, 6 \alpha, 27$-tetrahydroxy-1-oxo-with-2, 24-dienolide (4) (Figure 6) were proposed from the molecular ion peak at $m / z 488\left[\mathrm{M}^{+}\right.$(calcd for $\mathrm{C}_{28} \mathrm{H}_{40} \mathrm{O}_{7}, 488$ ) along with the fragment ions at $\mathrm{m} / z 226,120,100$ and 79 in the ESI-MS spectra of the control sample at $\mathrm{R}_{\mathrm{t}}$ of $6.85 \mathrm{~min}$ (Figure 2). In contrast, these compounds 1-4 exhibited the molecular ion peak at $m / z 489[\mathrm{M}+\mathrm{H}]^{+}$(calcd for $\mathrm{C}_{28} \mathrm{H}_{41} \mathrm{O}_{7}, 489$ ) and $506\left[\mathrm{M}+\mathrm{NH}_{4}\right]^{+}$(calcd for $\mathrm{C}_{28} \mathrm{H}_{44} \mathrm{O}_{7} \mathrm{~N}, 506$ ) along with the fragment ions at $\mathrm{m} / \mathrm{z} 120$ and 100 in the ESI-MS spectra of the Biofield Energy Treated sample at $\mathrm{R}_{\mathrm{t}}$ of 7.30 min (Figure 4).

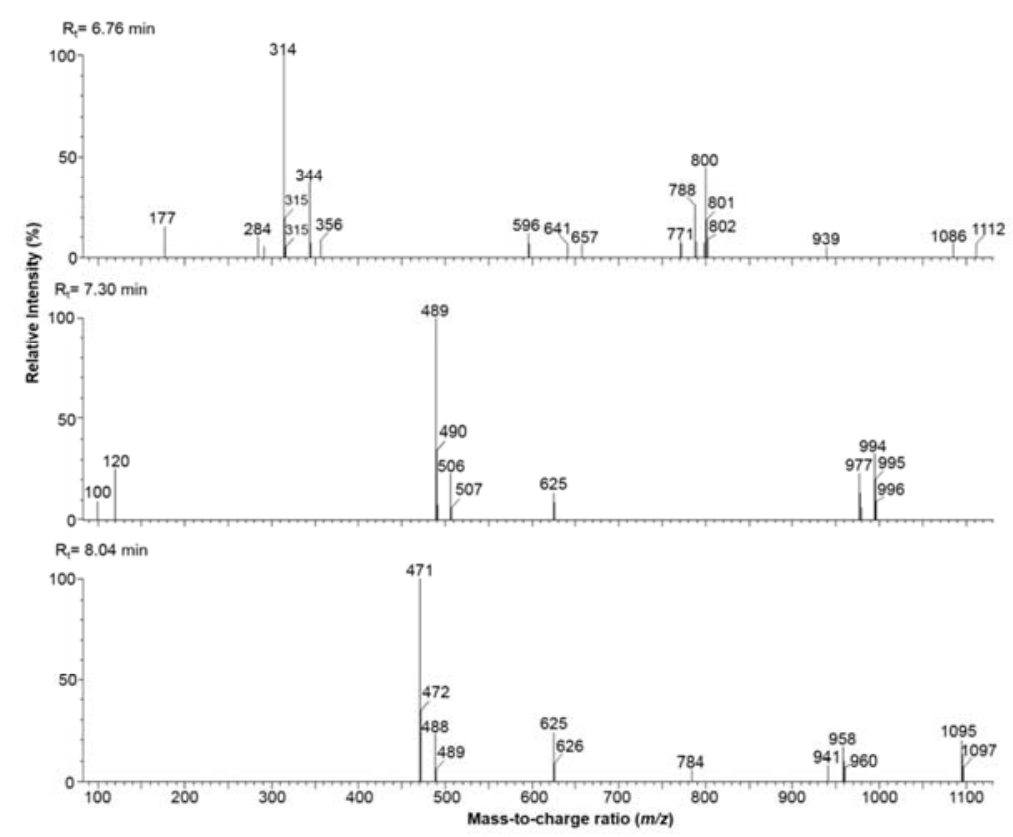

Figure 4. ESI-MS spectrum of the Biofield Energy Treated W. somnifera (Ashwagandha) root extract at the retention time 6.76, 7.30, and 8.04 min.

The GC-MS (Figure 7) and NMR (Figure 8) spectral analysis by following the literature [43] approach confirmed the presence of viscosa lactone B (1) or 27-hydroxy withanolide A (2) or $(20 S, 22 R)$-3 $\alpha, 6 \alpha$-epoxy-4 $\beta, 5 \beta$, 27-trihydroxy-1oxowitha-24-enolide (3) or $(20 S, 22 R)-4 \beta, 5 \beta, 6 \alpha, 27$-tetrahydroxy-1-oxo-with-2, 24-dienolide (4) (Figure 6) in the control and Biofield Energy Treated samples at $\mathrm{R}_{\mathrm{t}}$ of 6.85 and $7.30 \mathrm{~min}$, respectively.

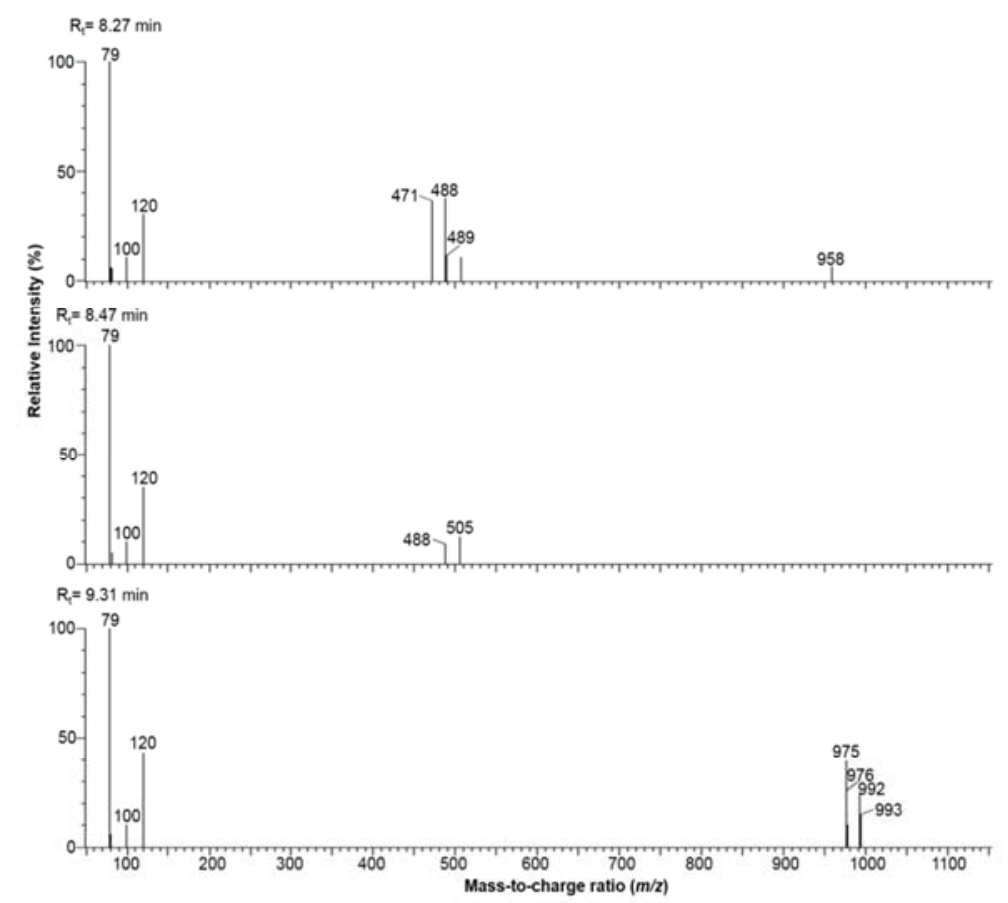

Figure 5. ESI-MS spectrum of the Biofield Energy Treated W. somnifera (Ashwagandha) root extract at the retention time 8.27, 8.47, and 9.31 min. 
Consequently, Dihydrowithanolide D (5) displayed the molecular ion peak at $m / z 473[\mathrm{M}+\mathrm{H}]^{+}$(calcd for $\mathrm{C}_{28} \mathrm{H}_{41} \mathrm{O}_{6}, 473$ ) and $490\left[\mathrm{M}+\mathrm{NH}_{4}\right]^{+}$(calcd for $\mathrm{C}_{28} \mathrm{H}_{44} \mathrm{O}_{6} \mathrm{~N}$, 490) along with fragment ions at $\mathrm{m} / z 120$ and 79 in the ESI-MS spectra of the control sample at the $\mathrm{R}_{\mathrm{t}}$ of $7.41 \mathrm{~min}$ (Figure 2) [43].
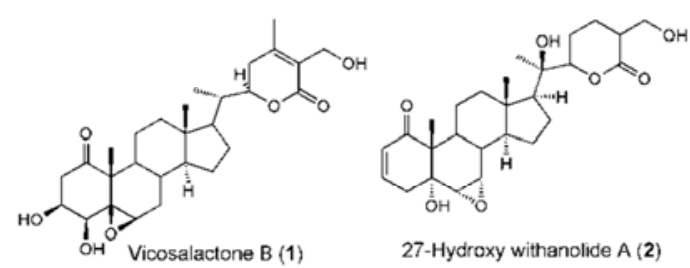

27-Hydroxy withanolide A (2)

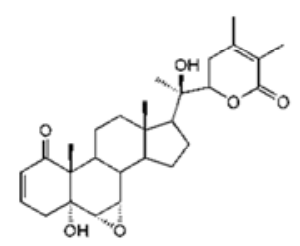

Withanolide A (6)

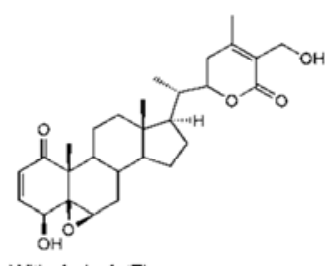

Withaferin $\mathrm{A}(\mathbf{7})$

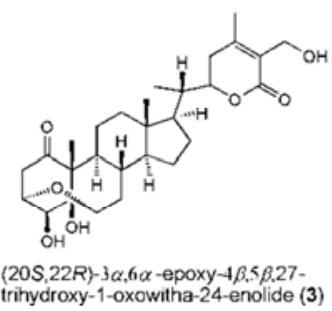

$(20 S, 22 R)-3 \alpha, 6 \alpha$-epoxy-4 $\beta, 5 \beta, 27-$
trihydroxy-1-oxowitha-24-enolide (3)

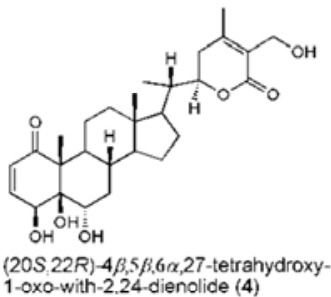

1-oxo-with-2,24-dienolide (4)
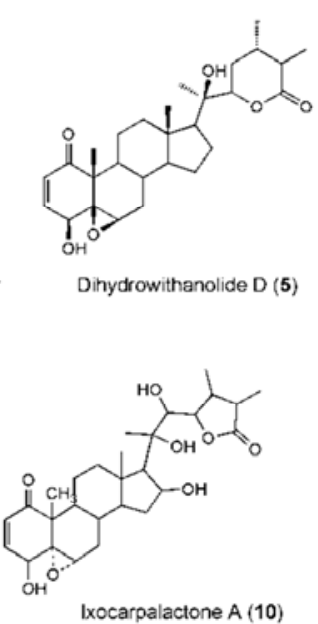
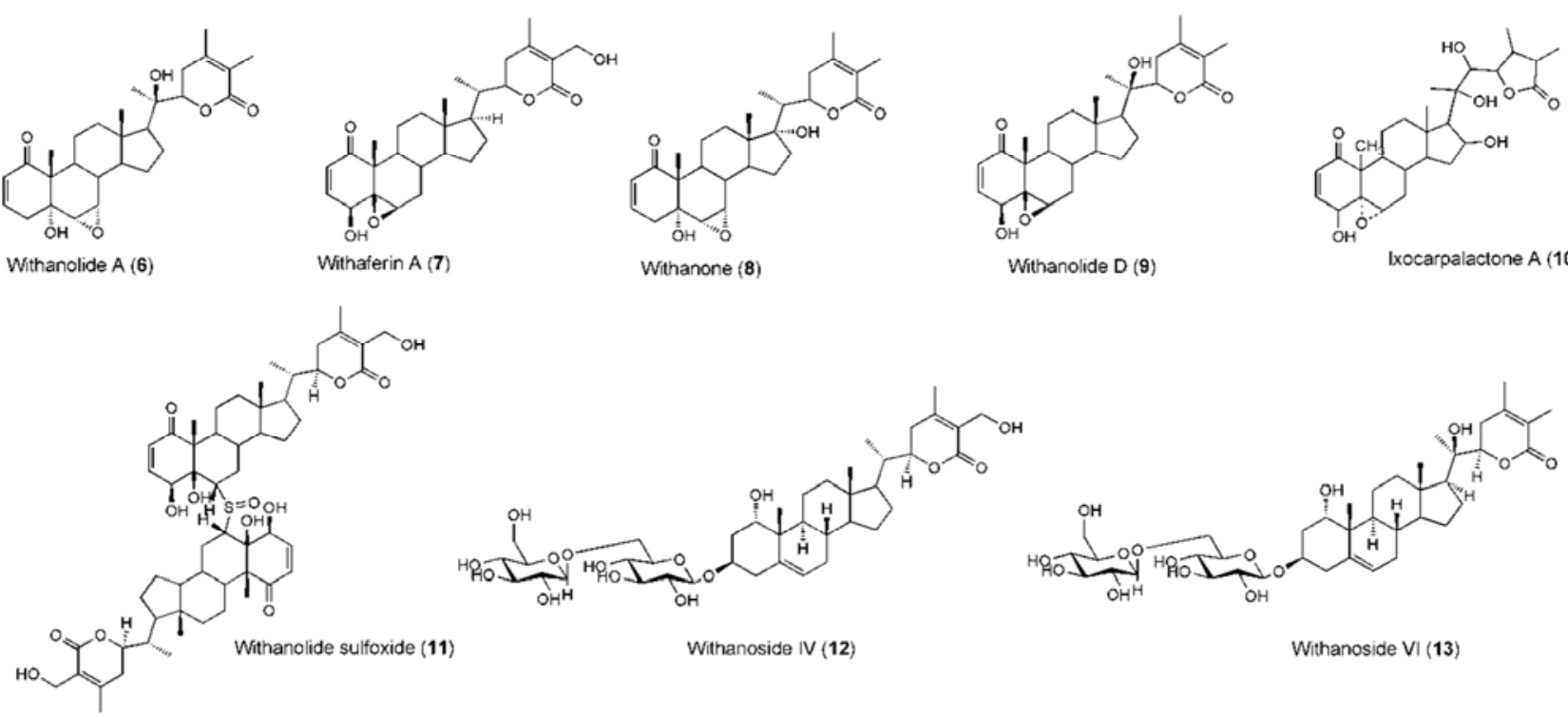

Figure 6. Structure of the proposed compounds 1-13.

By following approach in the recent literature [43], withanolide A (6), withaferin A (7), withanone (8), withanolide D (9) (Figure 6) can show the molecular ion peak at $m / z 471[\mathrm{M}+\mathrm{H}]^{+}$(calcd for $\mathrm{C}_{28} \mathrm{H}_{39} \mathrm{O}_{6}, 471$ ) and 488 $\left[\mathrm{M}+\mathrm{NH}_{4}\right]^{+}$(calcd for $\mathrm{C}_{28} \mathrm{H}_{42} \mathrm{O}_{6} \mathrm{~N}, 488$ ) along with fragment ions at $\mathrm{m} / \mathrm{z} 459,120$, and 100 in the ESI-MS spectra of the control and Biofield Energy Treated samples at the retention times 8.14, 8.36, 8.04 and $8.27 \mathrm{~min}$, respectively (Figures 25). The GC-MS (Figure 7) and NMR data (Figure 8) also supported the presence of any of compounds 6-9. The peaks at $\mathrm{R}_{\mathrm{t}}$ of 8.36 and 8.27 min displayed the most highest peaks in the LC of the control and treated samples, respectively (Figure 1 and Table 1). Hence, compound 6 or 7 or 8 or 9 was the major phytoconstituent in the control and Biofield Energy Treated samples. The molecular ion peak at $\mathrm{m} / \mathrm{z} 505$ $[\mathrm{M}+\mathrm{H}]^{+}$(calcd for $\mathrm{C}_{28} \mathrm{H}_{41} \mathrm{O}_{8}, 505$ ) and $522\left[\mathrm{M}+\mathrm{NH}_{4}\right]^{+}$ (calcd for $\mathrm{C}_{28} \mathrm{H}_{44} \mathrm{O}_{8} \mathrm{~N}$, 522) along with the fragment ions at $m / z 488\left[\mathrm{M}-\mathrm{H}_{2} \mathrm{O}+2 \mathrm{H}\right]^{+}, 471\left[\mathrm{M}-2 \mathrm{H}_{2} \mathrm{O}+3 \mathrm{H}\right]^{+}, 443,425$, 277, 272, 141, 120 and 100 in the ESI-MS spectra of the control and Biofield Energy Treated samples (Figure 3 and 5), respectively along with the GC-MS data (Figure 7) and NMR data (Figure 8) revealed the presence of ixocarpalactone A (10) (Figure 6) in the control and Biofield
Energy Treated ashwagandha root extract at $\mathrm{R}_{\mathrm{t}}$ of 8.55 and $8.47 \mathrm{~min}$. Consequently, the ESI-MS spectra of the control and Biofield Energy Treated samples at $R_{t}$ of 9.30 and 9.31 min (Figure 3 and 5) revealed that withanolide sulfoxide (11) (Figure 6) showed the molecular ion peak at $\mathrm{m} / z$ $992[\mathrm{M}+$ $\mathrm{H}]^{+}$(calcd for $\mathrm{C}_{56} \mathrm{H}_{79} \mathrm{O}_{13} \mathrm{~S}$, 992) along with the fragment ions at $\mathrm{m} / \mathrm{z}$ 975, 437, 141, 120 and 100. The GC-MS data (Figure $7 \mathrm{~b}$ ) and NMR data (Figure 8) indicated the presence of withanolide sulfoxide 11 (Figure 6) in both the control and Biofield Energy Treated samples which was only found in the ashwagandha root extract [45]. Withanoside IV (12) or withanoside VI (13) (Figure 6) exhibited the molecular ion peak at $800\left[\mathrm{M}+\mathrm{NH}_{4}\right]^{+}$(calcd for $\mathrm{C}_{40} \mathrm{H}_{66} \mathrm{O}_{15} \mathrm{~N}, 800$ ) along with the fragment ions at $\mathrm{m} / \mathrm{z} 788,771,657,641,596,356$, 344, 314, 284 and 177 in the ESI-MS spectrum of the Biofield Energy Treated sample at $\mathrm{R}_{\mathrm{t}}$ of $6.76 \mathrm{~min}$ (Figure 4). Consequently, the GC-MS data (Figure 7f) and NMR data (Figure $8 \mathrm{~b}$ and $\mathrm{d}$ ) also disclosed the presence of two glucopyranosyl moieties in the Biofield Energy Treated sample. Hence, withanoside IV (12) or withanoside VI (13) as shown in the Figure 6 might present in the Biofield Energy Treated sample at $\mathrm{R}_{\mathrm{t}}$ of $6.76 \mathrm{~min}$. 

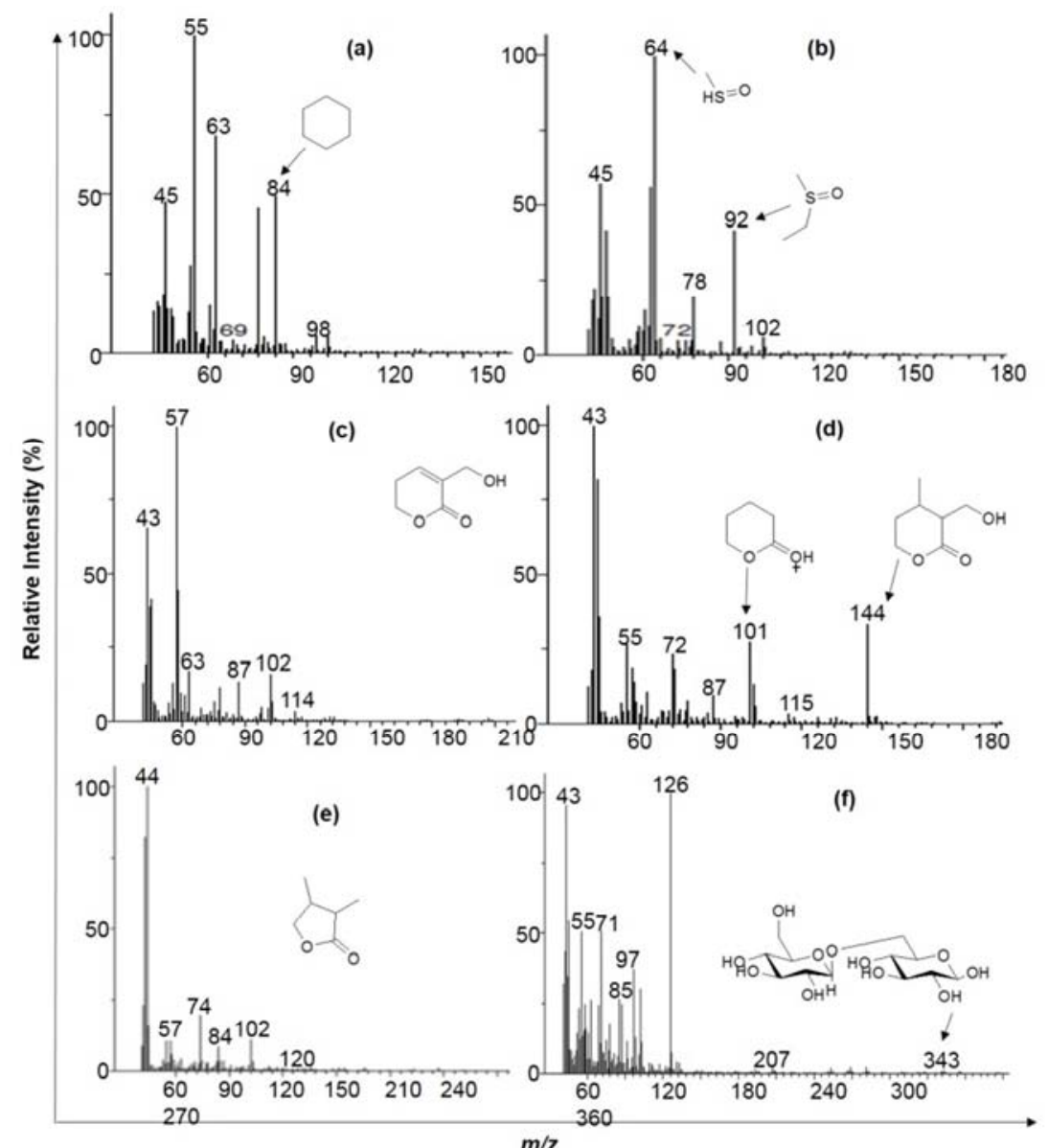

Figure 7. GC-MS spectra of the control and Biofield Energy Treated W. somnifera root extract with the proposed fragmentation of withanolides.
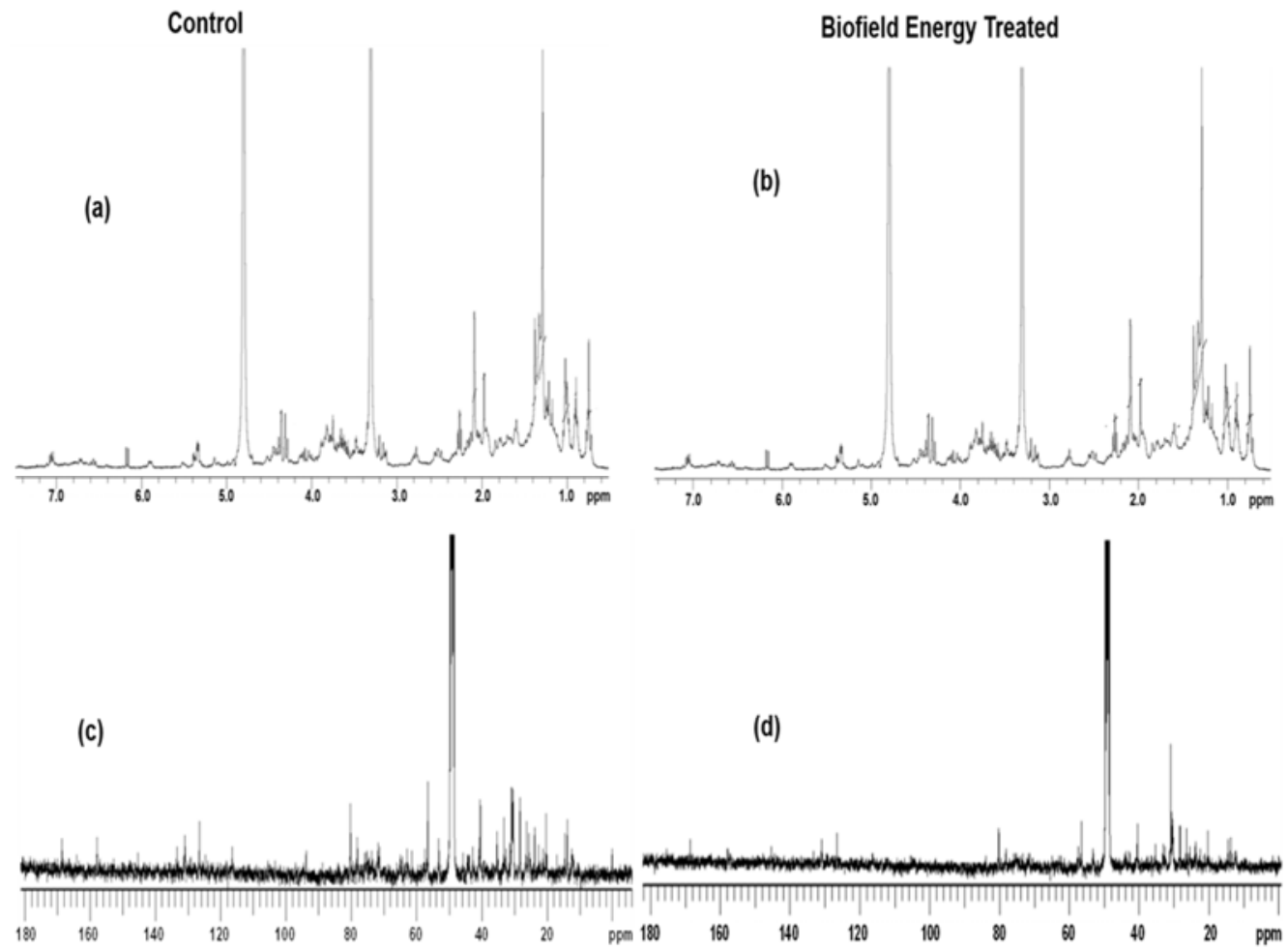

Figure 8. ${ }^{1} \mathrm{H}$ NMR spectra of the control (a) and Biofield Energy Treated (b); ${ }^{13} \mathrm{C}$ NMR spectra of the control (c), and Biofield Energy Treated (d) W. somnifera (Ashwagandha) root extract. 


\section{Conclusions}

The LC-MS, GC-MS, and NMR study on $W$. somnifera (Ashwagandha) root extract inferred that The Trivedi Effect ${ }^{\circledR}$ - Energy of Consciousness Healing Treatment has the significant effect on the peak area $\%$ i. e. the relative amount of the phytoconstituents without affecting their structural properties. The LC-ESI-MS/MS analysis demonstrated that the peak area\% of the Biofield Energy Treated sample at $\mathrm{R}_{\mathrm{t}}$ of $5.35,5.55,5.94,6.25,6.63,6.76,7.92,8.04,8.60,8.73$, and $9.31 \mathrm{~min}$ were significantly decreased in the range of $6.15 \%$ to $60.67 \%$ with respect to the control sample at $\mathrm{R}_{\mathrm{t}}$ of $5.43,5.65,5.95,6.29,6.76,6.85,8.03,8.14,8.68,8.78$, and $9.30 \mathrm{~min}$. In addition, the peak area\% of the Biofield Energy Treated sample at $R_{t}$ of $7.25,7.30,8.27$, and 8.47 min were significantly increased by $26.32 \%, 7.99 \%, 16.93 \%$ and $7.97 \%$ with respect to the control sample at $R_{t}$ of $7.37,7.41$, 8.36 , and $8.55 \mathrm{~min}$, respectively. A total of 13 withanolides were proposed with their structure from the deduced molecular mass at $\mathrm{m} / \mathrm{z} 470,472,488,504,782$, and 991 through the LC-MS, GC-MS, ${ }^{1} \mathrm{H}$ and ${ }^{13} \mathrm{C}$ NMR analysis of the both control and Biofield Energy Treated samples. The structure of the metabolites in W. somnifera root extract remained unchanged by the Biofield Energy Healing Treatment. Viscosa lactone B, 27-hydroxy withanolide A, $(20 S, 22 R)-3 \alpha, 6 \alpha$-epoxy-4 $\beta, 5 \beta, 27$-trihydroxy-1-oxowitha24-enolide, $(20 S, 22 R)-4 \beta, 5 \beta, 6 \alpha, 27$-tetrahydroxy-1-oxowith-2, 24-dienolide were proposed in the control and treated samples at $\mathrm{R}_{\mathrm{t}}$ of 6.85 and $7.30 \mathrm{~min}$, respectively. Dihydrowithanolide D was only identified in the control sample at $R_{t}$ of $7.41 \mathrm{~min}$, whereas withanoside IV or withanoside VI was only present in the Biofield Treated sample at $R_{t}$ of 6.76 min. Withanolide $A$, withaferin $A$, withanone, withanolide $\mathrm{D}$, ixocarpalactone $\mathrm{A}$ and withanolide sulfoxide were found in both the control and treated samples. The Trivedi Effect $^{\circledR}$ - Energy of Consciousness Healing Treatment could be valuable for altering the concentration of the phytoconstituents in the ashwagandha root extract by modifying their intrinsic physicochemical properties, which might be helpful to improve the bioavailability of active constituents of $W$. somnifera extract that might provide better therapeutic response against various diseases various diseases such as diabetes mellitus, allergies and septic shock; stress-related disorders like sleep disorder, insomnia, anxiety, depression, Attention Deficit Disorder (ADD), Attention Deficit Hyperactive Disorder (ADHD), mental restlessness (mind chattering), brain frog, low libido, impotency, lack of motivation, mood swings, fear of the future, confusion, migraines, headaches, forgetfulness, overwhelm, loneliness, worthlessness, indecisiveness, frustration, irritability, chronic fatigue, obsessive/compulsive behavior and panic attacks; inflammatory diseases and immunological disorders like Lupus, Systemic Lupus Erythematosus, Hashimoto Thyroiditis, Type 1 Diabetes, Asthma, Chronic peptic ulcers, Tuberculosis, Hepatitis, Chronic active hepatitis, Celiac
Disease (gluten-sensitive enteropathy), Addison Disease, Crohn's disease, Graves' Disease, Pernicious and Aplastic Anemia, Sjogren Syndrome, Irritable Bowel Syndrome (IBS), Multiple Sclerosis, Rheumatoid arthritis, Chronic periodontitis, Ulcerative colitis, Chronic sinusitis, Myasthenia Gravis, Atherosclerosis, Vasculitis, Dermatitis, Diverticulitis, Rheumatoid Arthritis, Reactive Arthritis, Alopecia Areata, Psoriasis, Scleroderma, Fibromyalgia, Chronic Fatigue Syndrome and Vitiligo; aging-related diseases like cardiovascular disease, arthritis, cancer, Alzheimer's disease, dementia, cataracts, osteoporosis, diabetes, hypertension, glaucoma, hearing loss, Parkinson's Disease, Huntington's Disease, Prion Disease, Motor Neuron Disease, Spinocerebellar Ataxia, Spinal muscular atrophy, Amyotrophic lateral sclerosis, Friedreich's Ataxia and Lewy Body Disease, chronic infections and much more.

\section{Abbreviations}

DMSO: Dimethyl sulfoxide, EI: Electron ionization, ESI: Electrospray ionization, LC-MS: Liquid chromatography-mass spectrometry, PDA: Photodiode Array, $\mathrm{R}_{\mathrm{t}}$ : Retention time, UPLC: Ultra-performance liquid chromatography, GC-MS: Gas chromatography-mass spectrometry, $m / z$ : Mass-to-charge ratio, NMR: Nuclear magnetic resonance spectroscopy.

\section{Acknowledgements}

The authors are grateful to GVK Biosciences Pvt. Ltd., Hyderabad, India, Trivedi Science, Trivedi Global, Inc. and Trivedi Master Wellness for their support throughout the work.

\section{References}

[1] Kesarwani K, Gupta R (2013) Bioavailability enhancers of herbal origin: An overview. Asian Pac J Trop Biomed 3: 253-266.

[2] Singh N, Bhalla M, Jager P, Gilca M (2011) An overview on ashwagandha: A rasayana (rejuvenator) of ayurveda. Afr J Tradit Complement Altern Med 8: 208-213.

[3] Kulkarni SK, Dhir A (2008) Withania somnifera: an Indian ginseng. Prog Neuropsychopharmacol Biol Psychiatry 32: 1093-1105.

[4] Dar NJ, Hamid A, Ahmad M (2015) Pharmacologic overview of Withania somnifera, the Indian ginseng. Cell Mol Life Sci 72: $4445-4460$.

[5] Mir BA, Khazir J, Mir NA, Hasan T-ul, Koul S (2012) Botanical, chemical and pharmacological review of Withania somnifera (Indian ginseng): an Ayurvedic medicinal plant. Indian J Drugs Dis 1: 147-160.

[6] Mishra LC, Singh BB, Dagenais S (2000) Scientific basis for the therapeutic use of Withania somnifera (Ashwagandha): A review. Altern Med Rev 5: 334-346.

[7] Kumar V, Dey A, Hadimani MB, Marcović T, Emerald M (2015) Chemistry and pharmacology of Withania somnifera: An update. Tang (Humanitas Medicine) 5: e1. 
[8] Bolleddula J, Fitch W, Vareed SK, Nair MG (2012) Identification of metabolites in Withania sominfera fruits by liquid chromatography and high-resolution mass spectrometry. Rapid Commun Mass Spectrom 26: 1277-1290.

[9] Mirjalili MH, Moyano E, Bonfill M, Cusido RM, Palazón J (2009) Steroidal lactones from Withania somnifera, an ancient plant for novel medicine. Molecules 14: 2373-2393.

[10] Singh A, Duggal S, Singh H, Singh J, Katekhaye S (2010) Withanolides: phytoconstituents with significant pharmacological activities. Int J Green Pharm 4: 229-237.

[11] Chen LX, He H, Qiu F (2011) Natural withanolides: An overview. Nat Prod Rep 28: 705-740.

[12] Budhiraja RD, Krishan P, Sudhir S (2000) Biological activity of withanolides. J Sci Ind Res 59: 904-911.

[13] Stenger VJ (1999) Bioenergetic fields. Sci Rev Alternative Med 3.

[14] Rogers, M (1989) Nursing: A Science of Unitary Human Beings. In J. P. Riehl-Sisca (ed.) Conceptual Models for Nursing Practice. $3^{\text {rd }}$ edition. Norwark: Appleton \& Lange.

[15] Rosa L, Rosa E, Sarner L, Barrett S (1998) A close look at therapeutic touch. JAMA 279: 1005-1010.

[16] Warber SL, Cornelio D, Straughn, J, Kile G (2004) Biofield energy healing from the inside. J Altern Complement Med 10: 1107-1113.

[17] Nelson LA, Schwartz GE (2005) Human biofield and intention detection: Individual differences. J Altern Complement Med 11: 93-101.

[18] Nemeth L (2008) Energy and biofield therapies in practice. Beginnings. Summer 28: 4-5.

[19] Koithan M (2009) Introducing complementary and alternative therapies. J Nurse Pract 5: 18-20.

[20] Trivedi MK, Patil S, Shettigar H, Mondal SC, Jana S (2015) The potential impact of biofield treatment on human brain tumor cells: A time-lapse video microscopy. J Integr Oncol 4: 141.

[21] Trivedi MK, Branton A, Trivedi D, Nayak G, Mondal SC, Jana S (2015) Antimicrobial sensitivity, biochemical characteristics and biotyping of Staphylococcus saprophyticus: An impact of biofield energy treatment. J Women's Health Care 4: 271.

[22] Trivedi MK, Branton A, Trivedi D, Nayak G, Shettigar H, Mondal SC, Jana S (2015) Effect of biofield energy treatment on Streptococcus group B: A postpartum pathogen. J Microb Biochem Technol 7: 269-273.

[23] Trivedi MK, Patil S, Shettigar H, Gangwar M, Jana S (2015) Effect of biofield treatment on antimicrobials susceptibility pattern of Acinetobacter baumannii - An Experimental Study. J Clin Diagn Res 3: 1.

[24] Trivedi MK, Branton A, Trivedi D, Nayak G, Bairwa K, Jana S (2015) Effect of biofield treatment on physical, thermal, and spectral properties of SFRE 199-1 Mammalian Cell Culture Medium. Advances in Biochemistry 3: 77-85.

[25] Trivedi MK, Branton A, Trivedi D, Nayak G, Gangwar M, Jana S (2015) Bacterial identification using 16S rDNA gene sequencing and antibiogram analysis on biofield treated
Pseudomonas fluorescens. Clin Med Biochemistry Open Access 1: 101.

[26] Trivedi MK, Branton A, Trivedi D, Nayak G, Mondal SC, Jana S (2015) Evaluation of antibiogram, genotype and phylogenetic analysis of biofield treated Nocardia otitidis. Biol Syst Open Access 4: 143.

[27] Trivedi MK, Branton A, Trivedi D, Nayak G, Gangwar M, Jana S (2015) Antibiogram, biochemical reactions, and genotypic pattern of biofield treated Pseudomonas aeruginosa. J Trop Dis 4: 181.

[28] Trivedi MK, Tallapragada RM, Branton A, Trivedi D, Nayak G, Latiyal O, Jana S (2015) Characterization of physical and structural properties of aluminum carbide powder: Impact of biofield treatment. J Aeronaut Aerospace Eng 4: 142.

[29] Trivedi MK, Tallapragada RM, Branton A, Trivedi D, Nayak G, Latiyal O, Jana S (2015) The Potential impact of biofield energy treatment on the atomic and physical properties of antimony tin oxide nanopowder. American Journal of Optics and Photonics 3: 123-128.

[30] Trivedi MK, Patil S, Tallapragada RM (2013) Effect of biofield treatment on the physical and thermal characteristics of vanadium pentoxide powders. J Material Sci Eng S 11: 001.

[31] Trivedi MK, Branton A, Trivedi D, Shettigar H, Bairwa K, Jana S (2015) Fourier transform infrared and ultravioletvisible spectroscopic characterization of biofield treated salicylic acid and sparfloxacin. Nat Prod Chem Res 3: 186.

[32] Trivedi MK, Patil S, Shettigar H, Bairwa K, Jana S (2015) Effect of biofield treatment on spectral properties of paracetamol and piroxicam. Chem Sci J 6: 98.

[33] Trivedi MK, Tallapragada RM, Branton A, Trivedi D, Nayak G, Latiyal O, Jana S (2015) Potential impact of biofield treatment on atomic and physical characteristics of magnesium. Vitam Miner 3: 129.

[34] Trivedi MK, Tallapragada RM, Branton A, Trivedi D, Nayak G, Mishra RK, Jana S (2015) Biofield treatment: A potential strategy for modification of physical and thermal properties of gluten hydrolysate and ipomoea macroelements. J Nutr Food Sci 5: 414.

[35] Trivedi MK, Branton A, Trivedi D, Nayak G, Bairwa K, Jana S (2015) Spectroscopic characterization of disodium hydrogen orthophosphate and sodium nitrate after biofield treatment. J Chromatogr Sep Tech 6: 282.

[36] Trivedi MK, Branton A, Trivedi D, Nayak G, Panda P, Jana S (2016) Gas chromatography-mass spectrometric analysis of isotopic abundance of ${ }^{13} \mathrm{C},{ }^{2} \mathrm{H}$, and ${ }^{18} \mathrm{O}$ in biofield energy treated $p$-tertiary butylphenol (PTBP). American Journal of Chemical Engineering 4: 78-86.

[37] Trivedi MK, Branton A, Trivedi D, Nayak G, Sethi KK, Jana S (2016) Gas chromatography-mass spectrometry based isotopic abundance ratio analysis of biofield energy treated methyl-2-napthylether (Nerolin). American Journal of Physical Chemistry 5: 80-86.

[38] Trivedi MK, Branton A, Trivedi D, Nayak G, Mondal SC, Jana S (2015) Evaluation of biochemical marker - glutathione and DNA fingerprinting of biofield energy treated Oryza sativa. American Journal of BioScience 3: 243-248.

[39] Trivedi MK, Branton A, Trivedi D, Nayak G, Gangwar M, Jana S (2016) Molecular analysis of biofield treated eggplant and watermelon crops. Adv Crop Sci Tech 4: 208. 
[40] Chatterjee S, Srivastava S, Khalid A, Singh N, Sangwan RS, Sidhu OP, Roy R, Khetrapal CL, Tuli R (2010) Comprehensive metabolic fingerprinting of Withania somnifera leaf and root extracts. Phytochemistry 71: 10851094.

[41] Chaurasiya ND, Uniyal GC, Lal P, Misra L, Sangwan NS, Tuli R, Sangwan RS (2008) Analysis of withanolides in root and leaf of Withania somnifera by HPLC with photodiode array and evaporative light scattering detection. Phytochem Anal 19: 148-154.

[42] Musharraf SG, Ali A, Ali RA, Yousuf S, Rahman AU, Choudhary MI (2011) Analysis and development of structurefragmentation relationships in withanolides using an electrospray ionization quadropole time-of-flight tandem mass spectrometry hybrid instrument. Rapid Commun Mass Spectrom 25: 104-114.

[43] Trivedi MK, Panda P, Sethi, KK, Jana S (2016) Metabolite profiling of Withania somnifera roots hydroalcoholic extract using LC-MS, GC-MS and NMR spectroscopy. Chem Biodivers. Article in press. doi:10.1002/cbdv.201600280

[44] https://www. scribd. com/document/220440935/Theory-ofHPLC-Quantitative-and-Qualitative-HPLC

[45] Mulabagal V, Subbaraju GV, Rao CV, Sivaramakrishna C, Dewitt DL, Holmes D, Sung B, Aggarwal BB, Tsay HS, Nair MG (2009) Withanolide sulfoxide from Aswagandha roots inhibits nuclear transcription factor- $\mathrm{\kappa B}$, cyclooxygenase and tumor cell proliferation. Phytother Res 23: 987-992. 